\title{
Food Availability at the Household Level in the European Union
}

\author{
On the Basis of Household Budget Surveys, Data from the DAFNE Databank
}

Comparable information on food availability between countries can be provided by data collected in the household budget surveys (HBS). The HBS can be thought of occupying a position between the food balance sheets of the FAO and the specially designed individual nutrition surveys. Like food balance sheets, the HBS allow between-country comparisons at a regular basis but, moving from total population to household level, the HBS can provide a more detailed and valid description of the dietary choices of the population, as well as of population sub-groups defined by their demographic and socioeconomic characteristics.

HBS, on which the DAFNE data are based [Trichopoulou et al., 2001; 2003], provide regularly updated dietary data that can be linked to sociodemographic indicators and are undertaken in nationally representative population samples. Since, however, they are not primarily designed to collect nutritional information, the food data have limitations which need to be taken into consideration [Southgate DAT, 1991; Trichopoulou A, 1992]. Thus in most cases, no records are collected on the type and quantity of food items and beverages consumed outside the home. With the exception of the UK where data on the out-of-home consumption have been recorded since 1992, the majority of the European countries collect data only on expenses related to this food occasion. Lastly, the HBS data are collected at household level and estimation of the individuals' intake requires the application of non-parametric modelling.

The data presented in this chapter refer to 12 DAFNE countries, which also participate in the European Nutrition and Health Report project and results are only presented based on the most recent dataset available for each country. The DAFNE database, however, comprises of food data for 16 European countries, spanned over the last 20 years. From the twelve countries presented, four are South European (Greece, Italy, Portugal and Spain), five are Central European (Austria, Belgium, France, Germany and Hungary) and three are North European (Finland, Norway and the UK).

From the socioeconomic indicators available in the DAFNE databank, we have chosen to present the effect of the household head's education on daily dietary practices. Education has been reported as the strongest and most consistent indicator in assessing socioeconomic differences [Liberatos, 1988]. Education expresses not only the individual's attainment and years of schooling, but it might also reflect occupation, income and, even more importantly, the way people perceive and apply current nutritional advice [Johansson et al., 1999]. Information on the educational level of the household head was available for ten out of the twelve countries studied.

\section{Food Availability}

Tables $4 a-4 c$ present the mean daily availability of DAFNE food groups, by European region and country. In Tables $5 \mathrm{a}$ and $5 \mathrm{~b}$, data on the daily food availability according to the educational level of the household head (defined as elementary, secondary and higher education) are also presented. The dietary patterns in Europe, as depicted using the DAFNE data comparable between countries, are summarised below for main DAFNE food groups. 
Table 4a. Mean availability of food and beverages in South European countries in the nineties (unit/person/day)

\begin{tabular}{|c|c|c|c|c|}
\hline Survey year & $\begin{array}{l}\text { Greece } \\
1998- \\
1999\end{array}$ & $\begin{array}{l}\text { Italy } \\
1996\end{array}$ & $\begin{array}{l}\text { Spain } \\
1990- \\
1991\end{array}$ & $\begin{array}{l}\text { Portugal } \\
1995\end{array}$ \\
\hline Eggs (pieces) & 0.25 & 0.34 & 0.56 & 0.23 \\
\hline Potatoes (g) & 137 & 76 & 143 & 230 \\
\hline Pulses (g) & 14 & 4.1 & 18 & 11 \\
\hline Nuts (g) & 4.7 & 0.9 & 2.1 & 2.4 \\
\hline Cereals (g) & 253 & 335 & 206 & 257 \\
\hline $\begin{array}{l}\text { Milk and milk } \\
\text { products }(\mathrm{g})\end{array}$ & 298 & 271 & 398 & 261 \\
\hline Cheese (g) & 53 & 49 & 19 & 11 \\
\hline $\begin{array}{l}\text { Meat and meat } \\
\text { products }(\mathrm{g})\end{array}$ & 149 & 136 & 176 & 163 \\
\hline Red meat (g) & 100 & 71 & 71 & 91 \\
\hline Poultry (g) & 39 & 38 & 58 & 48 \\
\hline Processed meat (g) & 8.7 & 24 & 41 & 14 \\
\hline Vegetables (g) & 271 & 184 & 179 & 147 \\
\hline Fresh vegetables (g) & 248 & 128 & 155 & 140 \\
\hline $\begin{array}{l}\text { Processed } \\
\text { vegetables (g) }\end{array}$ & 23 & 56 & 24 & 7.5 \\
\hline Fish and seafood $(\mathrm{g})$ & 45 & 38 & 74 & 85 \\
\hline Fruits $(\mathrm{g})$ & 306 & 233 & 289 & 175 \\
\hline Fresh fruit (g) & 305 & 232 & 286 & 173 \\
\hline Processed fruit (g) & 0.47 & 1.4 & 3.0 & 2.1 \\
\hline $\begin{array}{l}\text { Fruit and vegetable } \\
\text { juices }(\mathrm{ml})\end{array}$ & 23 & 9.6 & 18 & 1.6 \\
\hline Lipids, added (g) & 84 & 63 & 59 & 56 \\
\hline Animal fat (g) & 0.80 & 5.6 & 1.0 & 2.4 \\
\hline Vegetable fat (g) & 5.8 & 1.5 & 1.9 & 5.9 \\
\hline Vegetable oils (g) & 77 & 56 & 57 & 48 \\
\hline $\begin{array}{l}\text { Beverages, } \\
\text { alcoholic (ml) }\end{array}$ & 48 & 149 & 110 & 139 \\
\hline $\begin{array}{l}\text { Beverages, non- } \\
\text { alcoholic (ml) }\end{array}$ & 328 & 824 & 358 & 129 \\
\hline Soft drinks (ml) & 65 & 42 & 84 & 38 \\
\hline $\begin{array}{l}\text { Sugar and sugar } \\
\text { products }(\mathrm{g})\end{array}$ & N/A & 49 & 35 & 34 \\
\hline
\end{tabular}

$\mathrm{N} / \mathrm{A}=$ not available.

Source: The DAFNE databank (www.nut.uoa.gr).

\section{Potatoes and Other Starchy Roots}

The highest potato availability was recorded in Portugal (230 g/person/day in 1995) and the lowest in Italy (76 g/person/day in 1996). The majority of the Central and Northern European countries under study recorded a potato availability of around $100 \mathrm{~g} /$ person/day. With respect to the effect of education, in all countries the potato availability decreased as the educational level of the household head increased.

\section{Pulses (Legumes)}

Pulses, plant foods of high dietary fibre and protein content, can generally be considered as a food preferably consumed in South Europe. In Greece, Spain and Portugal the mean pulses availability exceeded $10 \mathrm{~g} /$ person/day, while in Central and North Europe the availability values barely exceeded $1 \mathrm{~g} /$ person/day. An exception stands for France and Hungary, which in 1991 recorded $4.9 \mathrm{~g} /$ person/day and $6.0 \mathrm{~g} /$ person/day, respectively. The consumption of pulses was also not popular in Italy, which recorded similar availability values with France $(4.1 \mathrm{~g} /$ person/day in Italy). With the exception of Finland and Germany, households of low educational level recorded higher values, even in countries where the consumption of pulses was not popular. In South Europe, the particularly high preference towards pulses consumption among households of elementary education probably reflects the adherence of these populations to traditional eating patterns.

\section{Cereals and Cereal Products}

The group of cereals and cereal products includes cereal grains, flour, rice and pasta (used as recipe ingredients), together with bread, rusks, pizza, and bakery products. As expected, Italy had the highest daily availability of these countries with $335 \mathrm{~g} /$ person/day. With the exception of Germany, where cereal availability was slightly elevated among highly educated households, individuals of elementary education recorded higher values of cereal availability within their households.

\section{Milk and Milk Products}

Different patterns were observed with respect to the daily individual availability of milk and milk products. In late 1990s, the highest availability values were recorded in Finland ( $507 \mathrm{~g} /$ person/day) and the lowest in Belgium (255g/person/day). Although a North/South gradient in consumption cannot be observed, an interesting pattern emerged when cheese was separated from the group. Countries consuming higher quantities of cheese, like Belgium (55g/person/day) and Greece ( $53 \mathrm{~g} /$ person/day), tended to consume lower quantities of milk and other milk products $(200 \mathrm{~g} /$ person/day and $246 \mathrm{~g} / \mathrm{person} /$ day, for Belgium and Greece, 
Table 4b. Mean availability of food and beverages in Central European countries in the nineties (unit/person/day)

\begin{tabular}{|c|c|c|c|c|c|}
\hline Survey year & $\begin{array}{l}\text { Austria } \\
\text { 1999-2000 }\end{array}$ & $\begin{array}{l}\text { Belgium } \\
1999\end{array}$ & $\begin{array}{l}\text { France } \\
1991\end{array}$ & $\begin{array}{l}\text { Germany } \\
1998\end{array}$ & $\begin{array}{l}\text { Hungary } \\
1991\end{array}$ \\
\hline Eggs (pieces) & 0.50 & 0.21 & 0.38 & 0.36 & 0.66 \\
\hline Potatoes (g) & 100 & 97 & 95 & 115 & 139 \\
\hline Pulses (g) & N/A & $\mathrm{N} / \mathrm{A}$ & 4.9 & 0.6 & 6.1 \\
\hline Nuts (g) & N/A & 2.64 & 1.7 & 7.5 & 3.2 \\
\hline Cereals (g) & 303 & 238 & 161 & 217 & 319 \\
\hline $\begin{array}{l}\text { Milk and milk } \\
\text { products (g) }\end{array}$ & 284 & 255 & 291 & 311 & 301 \\
\hline Cheese (g) & 28 & 55 & 48 & 55 & 11 \\
\hline $\begin{array}{l}\text { Meat and meat } \\
\text { products }(\mathrm{g})\end{array}$ & 182 & 127 & 161 & 132 & 190 \\
\hline Red meat (g) & 65 & 54 & 77 & 48 & 61 \\
\hline Poultry (g) & 23 & 25 & 36 & 16 & 52 \\
\hline Processed meat $(\mathrm{g})$ & 92 & 35 & 33 & 59 & 66 \\
\hline Vegetables (g) & 142 & 167 & 187 & 180 & 201 \\
\hline Fresh vegetables $(\mathrm{g})$ & 114 & 127 & 157 & 142 & 185 \\
\hline $\begin{array}{l}\text { Processed } \\
\text { vegetables (g) }\end{array}$ & 28 & 40 & 29 & 38 & 16 \\
\hline Fish and seafood $(\mathrm{g})$ & 9.3 & 21 & 19 & 16 & 4.4 \\
\hline Fruits $(\mathrm{g})$ & 192 & 123 & 157 & 182 & 159 \\
\hline Fresh fruit (g) & 186 & 117 & 153 & 169 & 149 \\
\hline Processed fruit (g) & 6.2 & 6.0 & 4.4 & 13 & 10 \\
\hline $\begin{array}{l}\text { Fruit and vegetable } \\
\text { juices (ml) }\end{array}$ & 90 & 54 & 33 & 123 & N/A* \\
\hline Lipids, added (g) & 42 & 29 & 41 & 37 & 53 \\
\hline Animal fat (g) & 12 & 7.6 & 16 & 15 & 30 \\
\hline Vegetable fat (g) & 11 & 13 & 5.9 & 15 & 7.5 \\
\hline Vegetable oils (g) & 2.9 & 8.4 & 19 & 6.4 & 15 \\
\hline $\begin{array}{l}\text { Beverages, } \\
\text { alcoholic }(\mathrm{ml})\end{array}$ & 171 & 135 & 114 & 200 & 85 \\
\hline $\begin{array}{l}\text { Beverages, } \\
\text { non-alcoholic (ml) }\end{array}$ & 652 & 500 & 373 & 915 & N/A \\
\hline Soft drinks (ml) & 116 & 191 & 47 & 108 & 41 \\
\hline $\begin{array}{l}\text { Sugar and sugar } \\
\text { products }(\mathrm{g})\end{array}$ & 74 & 56 & 44 & 59 & 80 \\
\hline \multicolumn{6}{|c|}{$\begin{array}{l}\text { N/A = not available. } \\
* \text { Fruit and vegetable juices are grouped in the processed fruit and vegetables categories, } \\
\text { respectively. } \\
\text { Source: The DAFNE databank (www.nut.uoa.gr). }\end{array}$} \\
\hline
\end{tabular}

respectively). Among all the DAFNE countries, the highest milk and milk product availability (excluding cheese) was noted in Ireland ( $465 \mathrm{~g} /$ person/day), where the household consumption of cheese was rather low $(15 \mathrm{~g} / \mathrm{person} /$ day). Higher milk and milk product availability was recorded in households of lower education in Austria, Finland, Norway, Spain and to a lesser extent in France and Italy. Higher availabilities were noted among households of college/university education in Belgium, Germany, Greece, Portugal and Norway. The increase in milk and milk product availability as the educational level increased, particularly in countries where cheese was preferred, agreed with findings that cheese was more frequently consumed by individuals of college and university education.

\section{Meat and Meat Products}

Based on data collected in the nineties, the lowest meat and meat product availability was recorded in Norway (126 g/person/day) and the highest in Hungary 
Table 4c. Mean availability of food and beverages in Northern European countries in the nineties (unit/person/day)

\begin{tabular}{|c|c|c|c|}
\hline Survey year & $\begin{array}{l}\text { Finland } \\
1998\end{array}$ & $\begin{array}{l}\text { Norway } \\
1996 / 1997 / \\
1998\end{array}$ & $\begin{array}{l}\text { United } \\
\text { Kingdom } \\
1999\end{array}$ \\
\hline Eggs (pieces) & 0.31 & 0.34 & 0.24 \\
\hline Potatoes $(\mathrm{g})$ & 111 & 114 & 128 \\
\hline Pulses (g) & 1.3 & 0.82 & 0.99 \\
\hline Nuts (g) & 1.6 & 3.8 & 1.7 \\
\hline Cereals (g) & 206 & 201 & 199 \\
\hline Milk and milk products (g) & 507 & 386 & 320 \\
\hline Cheese (g) & 48 & 39 & 20 \\
\hline Meat and meat products $(\mathrm{g})$ & 148 & 126 & 130 \\
\hline Red meat $(\mathrm{g})$ & 52 & 53 & 34 \\
\hline Poultry (g) & 12 & 14 & 33 \\
\hline Processed meat (g) & 67 & 41 & 25 \\
\hline Vegetables $(\mathrm{g})$ & 123 & 109 & 150 \\
\hline Fresh vegetables (g) & 103 & 84 & 103 \\
\hline Processed vegetables (g) & 20 & 24 & 48 \\
\hline Fish and seafood $(\mathrm{g})$ & 30 & 50 & 20 \\
\hline Fruits $(g)$ & 157 & 135 & 106 \\
\hline Fresh fruit $(\mathrm{g})$ & 147 & 129 & 99 \\
\hline Processed fruit (g) & 11 & 6.1 & 7.6 \\
\hline $\begin{array}{l}\text { Fruit and vegetable } \\
\text { juices }(\mathrm{ml})\end{array}$ & 82 & 48 & 41 \\
\hline Lipids, added (g) & 31 & 32 & 26 \\
\hline Animal fat $(\mathrm{g})$ & 11 & 6.4 & 9.7 \\
\hline Vegetable fat $(\mathrm{g})$ & 16 & 23 & 11 \\
\hline Vegetable oils (g) & 3.5 & 1.7 & 6.0 \\
\hline $\begin{array}{l}\text { Beverages, } \\
\text { alcoholic (ml) }\end{array}$ & 102 & 73 & 51 \\
\hline $\begin{array}{l}\text { Beverages, non- } \\
\text { alcoholic }(\mathrm{ml})\end{array}$ & 531 & 720 & 812 \\
\hline Soft drinks (ml) & 81 & 177 & 202 \\
\hline $\begin{array}{l}\text { Sugar and sugar } \\
\text { products }(\mathrm{g})\end{array}$ & 53 & 79 & 31 \\
\hline
\end{tabular}

Source: The DAFNE databank (www.nut.uoa.gr).

$(190 \mathrm{~g} /$ person/day). Interesting disparities further emerged when different types of meat were studied. The highest red meat consumer was Greece ( $100 \mathrm{~g} /$ person/ day in 1998-1999) indicating the country's departure from the eating habits in early 1960 s, when meat consumption was substantially lower. Poultry was consumed more in Spain (58 g/person/day) and Hungary ( $52 \mathrm{~g} /$ person/day); while a preference towards the consumption of processed meat could be noted in Central Europe. With the exception of Portugal, a social gradient in the availability of meat and meat products was noted, with the daily availability values decreasing as the educational level of the household increased. Although this pattern generally remained when different meat types were also studied, it should be noted that in Greece households of higher education consumed slightly more meat products, and the Norwegian highly educated households recorded higher poultry availability values, when compared to their lower educated counterparts.

\section{Fish and Seafood}

Portugal had the highest fish availability with $85 \mathrm{~g} /$ person/day, followed by Spain $(74 \mathrm{~g} /$ person/day), Norway ( $50 \mathrm{~g} /$ person/day) and Greece ( $45 \mathrm{~g} /$ person/day). The lowest fish and seafood availability was recorded in Austria in 1999-2000 (9.3 g/person/day) and in Hungary in 1991 (4.4 g/person/day), probably reflecting distance from the sea. Urban areas generally recorded higher fish consumption, indicating the recent improvement of food availability in urban markets (DAFNE data on locality not shown). Fish availability was found to differ between different education attainment levels in Austria, where fish availability increased as the educational level of the household head increased, and in Norway, Finland, Spain and Greece, where elementary educated households recorded higher fish availability. It should however be noted that, in recent years, the Greek low educated households had the biggest increase in fish availability, while in Norway highly educated households increased their fish consumption more than the low educated ones (DAFNE data on time trends not shown).

\section{Vegetables (Fresh and Processed)}

According to HBS data collected in the late 1990s, Greece recorded the highest vegetable availability within the household ( $271 \mathrm{~g} /$ person/day). Finland and Norway, the two Scandinavian countries of the DAFNE network recorded the lowest vegetable availabilities $(123 \mathrm{~g} / \mathrm{per}-$ son/day and $109 \mathrm{~g} /$ person/day, respectively). South European countries were expected to be identified as the higher vegetable consumers; nonetheless, several Central European countries recorded availability values of similar magnitude. An increase in the availability of fruit, and vegetables in many Northern and Western European countries has been documented in recent years. In southern Europe, fruit and vegetable intakes have not shown the same increase, although they began at a much higher baseline. Given current recommendations for at least 3 
Table 5a. Mean availability of foods and beverages ( $\mathrm{g}-\mathrm{ml} /$ person/day) by country (survey year) and educational attainment

\begin{tabular}{|c|c|c|c|c|c|c|c|c|c|c|c|c|c|c|c|}
\hline & \multicolumn{3}{|c|}{$\begin{array}{l}\text { Austria } \\
(1999-2000)\end{array}$} & \multicolumn{3}{|c|}{$\begin{array}{l}\text { Greece } \\
(1998-1999)\end{array}$} & \multicolumn{3}{|c|}{$\begin{array}{l}\text { Italy } \\
(1996)\end{array}$} & \multicolumn{3}{|c|}{$\begin{array}{l}\text { Portugal } \\
\text { (1995) }\end{array}$} & \multicolumn{3}{|c|}{$\begin{array}{l}\text { Spain } \\
(1990-1991)\end{array}$} \\
\hline & $\mathrm{Il} / \mathrm{El}$ & $\mathrm{Sec}$ & $\mathrm{C} / \mathrm{U}$ & $\mathrm{Il} / \mathrm{El}$ & $\mathrm{Sec}$ & $\mathrm{C} / \mathrm{U}$ & $\mathrm{Il} / \mathrm{El}$ & $\mathrm{Sec}$ & $\mathrm{C} / \mathrm{U}$ & $\mathrm{Il} / \mathrm{El}$ & $\mathrm{Sec}$ & $\mathrm{C} / \mathrm{U}$ & $\mathrm{Il} / \mathrm{El}$ & $\mathrm{Sec}$ & $\mathrm{C} / \mathrm{U}$ \\
\hline $\begin{array}{l}\text { Cereals and cereal } \\
\text { products }(\mathrm{g})\end{array}$ & 339 & 302 & 305 & 295 & 224 & 206 & 367 & 320 & 289 & 315 & 270 & 224 & 220 & 164 & 155 \\
\hline $\begin{array}{l}\text { Meat and meat } \\
\text { products }(\mathrm{g})\end{array}$ & 197 & 185 & 140 & 155 & 144 & 144 & 149 & 130 & 118 & 150 & 168 & 155 & 182 & 160 & 147 \\
\hline Poultry (g) & 28 & 23 & 18 & 41 & 36 & 37 & 43 & 35 & 33 & 56 & 50 & 42 & 62 & 48 & 43 \\
\hline Processed meat (g) & 87 & 93 & 83 & 7.2 & 9.6 & 11 & 25 & 24 & 20 & 12 & 15 & 12 & 42 & 40 & 35 \\
\hline Fish and seafood $(\mathrm{g})$ & 7.1 & 9.0 & 12 & 49 & 41 & 45 & 38 & 37 & 38 & 81 & 86 & 79 & 75 & 71 & 70 \\
\hline $\begin{array}{l}\text { Milk and milk } \\
\text { products }(\mathrm{g})\end{array}$ & 343 & 285 & 267 & 267 & 307 & 360 & 276 & 269 & 266 & 208 & 247 & 280 & 402 & 378 & 389 \\
\hline Fruit (g) & 260 & 191 & 191 & 291 & 299 & 358 & 242 & 227 & 231 & 139 & 172 & 171 & 293 & 273 & 278 \\
\hline Fresh fruit (g) & 255 & 185 & 182 & 291 & 299 & 357 & 241 & 226 & 230 & 138 & 170 & 169 & 290 & 270 & 275 \\
\hline Proc. fruit (g) & 4.9 & 5.9 & 9.9 & 0.37 & 0.42 & 0.85 & 1.2 & 1.5 & 1.3 & 0.88 & 1.9 & 2.2 & 3.1 & 3.1 & 2.9 \\
\hline $\begin{array}{l}\text { Fruit and vegetable } \\
\text { juices }(\mathrm{ml})\end{array}$ & 94 & 87 & 117 & 15 & 26 & 37 & 6.6 & 11 & 12 & 1.1 & 1.3 & 1.5 & 17 & 23 & 22 \\
\hline Potatoes (g) & 151 & 103 & 67 & 146 & 134 & 117 & 85 & 71 & 69 & 291 & 245 & 198 & 156 & 101 & 94 \\
\hline Pulses (g) & $\mathrm{N} / \mathrm{A}$ & N/A & N/A & 18 & 11 & 9.9 & 4.4 & 4.0 & 3.7 & 16 & 13 & 8.1 & 20 & 13 & 11 \\
\hline Lipids, added (g) & 67 & 43 & 30 & 94 & 74 & 80 & 71 & 59 & 51 & 63 & 58 & 47 & 62 & 49 & 52 \\
\hline Animal lipids (g) & 14 & 12 & 11 & 0.63 & 0.84 & 1.2 & 6.3 & 5.2 & 5.0 & 1.6 & 1.9 & 2.2 & 0.94 & 0.93 & 1.9 \\
\hline Vegetable fats (g) & 12 & 11 & 6.2 & 5.6 & 6.0 & 6.1 & 1.6 & 1.5 & 1.2 & 5.5 & 5.9 & 5.9 & 1.8 & 2.1 & 2.4 \\
\hline Vegetable oils (g) & 40 & 20 & 13 & 88 & 67 & 73 & 64 & 52 & 45 & 55 & 51 & 39 & 59 & 46 & 48 \\
\hline
\end{tabular}

$\mathrm{N} / \mathrm{A}=$ not available; $\mathrm{Il} / \mathrm{EL}=$ illiterate/elementary education; $\mathrm{Sec}=$ secondary education; $\mathrm{C} / \mathrm{U}=$ college/university.

Source: The DAFNE databank (www.nut.uoa.gr).

portions of vegetables (approx. $250 \mathrm{~g} /$ person/day) on a daily basis, Europeans are still far from meeting this target. If we further consider that the presented values refer to vegetable purchases, which are generally higher than the actual intake, the deficit is more pronounced. In terms of socioeconomic disparities in vegetable consumption, South Europe elementary education was found to be associated with higher vegetable availability. The picture was, however, reversed in Central and Northern Europe. With the exception of Austria and France, the highest vegetable availability was noted for the trend-leading highly educated households.
Food Availability at the Household Level in the European Union

\section{Fruits (Fresh and Processed)}

Fruits, together with vegetables, are the two food groups most frequently mentioned for their beneficial attributes. In the case of fruits, all the Mediterranean countries clearly lead the way with a mean daily availability exceeding the WHO recommendations of at least 2 portions (approx. $150 \mathrm{~g}$ ) of fruit per day. In Central Europe, Austria and Germany recorded household fruit consumption of more than $180 \mathrm{~g} /$ person/day; the lowest values were recorded in the United Kingdom (106 g/ person/day). In general, the highest fruit consumers are 
Table 5b. Mean availability of foods and beverages ( $\mathrm{g}-\mathrm{ml} /$ person/day) by country (survey year) and educational attainment

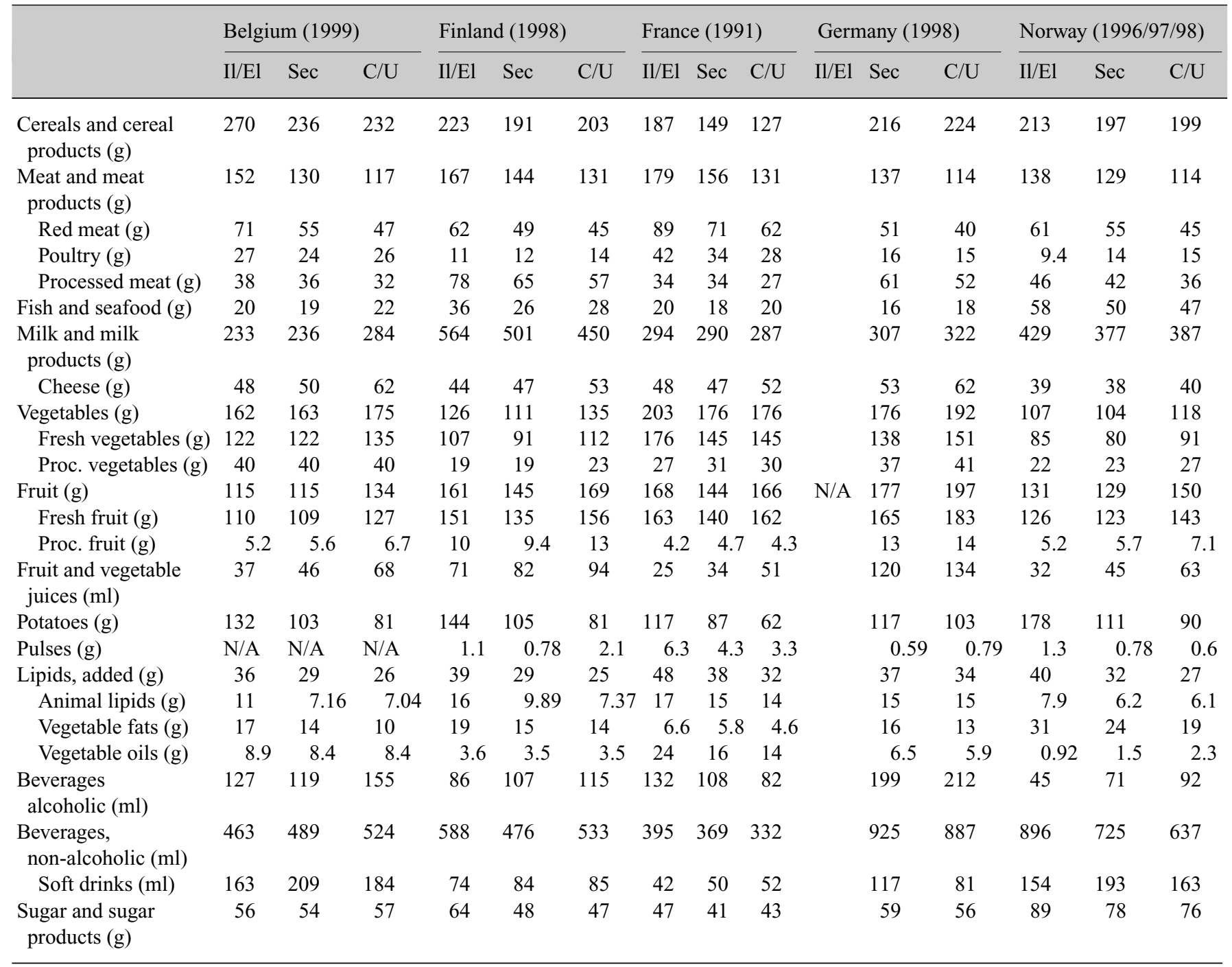

$\mathrm{Il} / \mathrm{EL}=$ illiterate/elementary education; Sec $=$ secondary education; $\mathrm{C} / \mathrm{U}=$ college/university; $\mathrm{N} / \mathrm{A}=$ not available.

Source: The DAFNE databank (www.nut.uoa.gr).

of college or university education. An exception stands for Austria, Italy and Spain, where the association between household fruit availability and educational attainment was reversed.

\section{Juices (Fruit and Vegetable)}

Because of the increased importance fruit and vegetable juices gain in consumers' preference, this beverage group is separately addressed in the DAFNE classification scheme. In the twelve countries under study, the range of availability values was substantially large and ranges between $1.6 \mathrm{ml} /$ person/day in Portugal and $123 \mathrm{ml} /$ person/day in Germany. It should further be noted that countries which were identified as high fruit consumers reported lower juice consumption. In terms of socioeconomic disparities, in all countries and survey years, juices were preferably consumed by highly educated individuals, or individuals exercising nonmanual professions (DAFNE data on occupation not shown). 


\section{Total Added Lipids}

The added lipid group includes all added fats (e.g. butter, margarine) and oils (olive oil and seed oils). As expected the highest lipid availabilities were noted in Greece ( $84 \mathrm{~g} /$ person/day), Italy (63 g/person/day) and Spain $(59 \mathrm{~g} /$ person/day), with olive oil being the predominant added lipid (data not shown). When different types of lipids were examined, regional disparities prominently emerged. South Europeans consumed mainly vegetable oils. Margarine was mostly preferred in the Scandinavian countries, the UK and to some extent in Germany and Austria. In the latter two countries, as well as in France, animal fat mostly in the form of butter was also commonly purchased for household consumption. The highest availability of animal fat was recorded in 1991 in Hungary $(30 \mathrm{~g} /$ person/day). Irrespective of differences in the type of dietary lipid consumed, in all countries lipid availability was higher among households of elementary education, indicating that high lipid availability may be related to traditional eating patterns.

\section{Alcoholic Beverages}

The lack of information on meals and beverages consumed outside the household is expected to impair observations related to the alcoholic beverage intake. It should thus be considered, when interpreting HBS data, that values on alcohol intake are only related to household availability. In this context, the highest availability values were recorded in Germany $(200 \mathrm{ml} /$ person/day) and the lowest in the UK and Greece (51 and $48 \mathrm{ml} /$ person/day, respectively). With the exception of the two Scandinavian countries, Belgium and Germany, more alcoholic drinks were available in households with heads of elementary education.

\section{Non-Alcoholic Beverages}

In accordance to alcoholic beverages, due caution is also required when interpreting data on the daily availability of non-alcoholic beverages (including soft drinks, mineral water, coffee and tea) at household level. As mineral water, coffee, tea and similar infusions are included in the grouping, Germany was leading the availability $(915 \mathrm{ml} /$ person/day), followed by Italy and the UK $(824 \mathrm{ml} /$ person/day and $812 \mathrm{ml} /$ person/day, respectively). Because of the public health implications, data are separately presented for the soft drinks availability, within the European households. The highest values were recorded in the UK $(202 \mathrm{ml} /$ person/day), followed by Belgium $(191 \mathrm{ml} /$ person/day) and Norway $(177 \mathrm{ml} /$ person/day). The lowest soft drink availability at household level was recorded in South European countries, France and Hungary. With the exception of three South European countries, Greece, Portugal and Spain, the availability of non-alcoholic beverages decreased as the education of the household head increased.

\section{Sugar and Sugar Products}

The highest daily availabilities of sugar and sugar products were recorded in Hungary ( $80 \mathrm{~g} /$ person/day), Norway ( $79 \mathrm{~g} /$ person/day) and Austria ( $74 \mathrm{~g} /$ person/ day). In response to current nutritional trends, most of the countries recorded a decrease in the availability of these products over time (DAFNE data on time trends not shown). In general, sugar and sugar product availability was higher among households of elementary education.

The findings on how education affects food availability agree well with recent observations that low educational level, and by extension low socioeconomic status, was generally associated with increased consumption of sugar products, potatoes, cereals (including bread), meat and meat products and lower consumption of fresh fruit [Hulshof et al., 1991; Smith and Baghurst, 1992; Roos et al., 1996; Johansson et al., 1999; Irala-Estevez et al., 2002]. However, it was observed that lower educational levels were associated with higher availability of fresh fruit in Southern European countries. The observation that fresh vegetable and legume availability decreased with the educational level of the household head may reflect the adherence of less educated Southern households to traditional dietary choices. The data retrieved from the DAFNE databank supported previous findings on disparities in food habits among the various European regions. 